\title{
SWARD STRUCTURE AND NUTRITIVE VALUE OF UROCHLOA RUZIZIENSIS UNDER NITROGEN AND POTASSIUM FERTILISATION ${ }^{1}$
}

\author{
KARLA RODRIGUES DE LIMA ${ }^{2 *}$, CARLOS AUGUSTO BRANDÃO DE CARVALHO ${ }^{3}$, FLAVIO HENRIQUE \\ VIDAL AZEVEDO ${ }^{2}$, PEDRO ANTONIO MUNINZ MALAFAIA ${ }^{3}$
}

\begin{abstract}
This study aimed to assess the effect of nitrogen $(\mathrm{N})$ and potassium $(\mathrm{K})$ fertilisation on the forage accumulation and nutritive value of Urochloa ruziziensis during the summer of 2010/2011 and autumn, winter, spring and summer of 2011/2012. A complete randomised block design with four treatments $(0,120$, 240 and $360 \mathrm{~kg} \mathrm{ha}^{-1}$ year $^{-1} \mathrm{~N}$ and $\mathrm{K}_{2} \mathrm{O}$ ) and five replicates were used. The data were analysed under the PROC MIXED of SAS ${ }^{\circledR}$. The following variables were evaluated: sward height; forage mass; forage bulk density; percentages of leaf blade dry matter, stem dry matter, and dead material dry matter; leaf blade:stem ratio; contents of dry matter and crude protein; in vitro digestibility of dry matter; neutral detergent fibre content; and lignin content of Urochloa ruziziensis. There was an interaction between the $\mathrm{N}$ and $\mathrm{K}$ levels of fertilisation and the season for all variables. In addition, there was a positive linear effect of the $\mathrm{N}$ and $\mathrm{K}$ levels of fertilisation on the forage accumulation rate, the crude protein content and the in vitro digestibility of dry matter and a negative linear effect these levels on the neutral detergent fibre and lignin contents during the spring and summer of 2011/2012. N and K fertilisation and the climate changes characteristic of each season jointly affected the accumulation and nutritive value of Urochloa ruziziensis. $\mathrm{N}$ and $\mathrm{K}$ fertilisation up to $360 \mathrm{~kg} \mathrm{ha}^{-1}$ year $^{-1}$ improved the forage accumulation and nutritive value of Urochloa ruziziensis.
\end{abstract}

Keywords: Crude protein. Forage mass. Lignin. Neutral detergent fibre. Sward height.

\section{ESTRUTURA DO DOSSEL E VALOR NUTRITIVO DE UROCHLOA RUZIZIENSIS SOB ADUBAÇÃO NITROGENADA E POTÁSSICA}

RESUMO - Este estudo objetivou avaliar o efeito da adubação com nitrogênio $(\mathrm{N})$ e potássio $(\mathrm{K})$ sobre o acúmulo o valor nutritivo da forragem da Urochloa ruziziensis, durante as estações de verão de 2010/2011 (verão 1), outono, inverno, primavera e verão de 2011/2012. Foi utilizado o delineamento em blocos completos casualizados com quatro tratamentos $\left(0,120,240\right.$ e $360 \mathrm{~kg} \mathrm{ha}^{-1}$ year $^{-1}$ de $\mathrm{N}$ e $\left.\mathrm{K}_{2} \mathrm{O}\right)$ e cinco repetições. Os dados foram analisados pelo PROC MIXED do $\mathrm{SAS}^{\circledR}$. Foram avaliadas as variáveis: altura do dossel, massa de forragem, densidade volumétrica da forragem; porcentagens de massas secas de lâminas foliares, colmos de material morto; relação lâmina: colmo; teores de matéria seca, proteína bruta e digestibilidade in vitro da matéria seca, fibra em detergente neutro, lignina da forragem da Urochloa ruziziensis. Houve efeito de interação entre doses de adubação com $\mathrm{N}$ e K e estação do ano para todas as variáveis. Também houve efeito linear positivo de doses de fertilização com $\mathrm{N}$ e $\mathrm{K}$ sobre a taxa de acúmulo de forragem, o teor de proteína bruta e da digestibilidade in vitro da matéria seca, e efeito linear negativo sobre os teores de fibra em detergente neutro e de lignina durante a primavera e o verão 2. A adubação com $\mathrm{N}$ e $\mathrm{K}$ e as mudanças climáticas características de cada estação afetam de forma conjunta o acúmulo e valor nutritivo da Urochloa ruziziensis. A adubação com $\mathrm{N}$ e K com até $360 \mathrm{~kg} \mathrm{ha}^{-1} \mathrm{ano}^{-1}$ aumenta o acúmulo de foragem e o valor nutritivo de Urochloa ruziziensis.

Palavras-chave: Proteína bruta. Massa de forragem. Lignina. Fibra em detergente neutro. Altura do dossel.

\footnotetext{
*Corresponding author

${ }^{1}$ Received for publication in $05 / 25 / 2015$; accepted in $09 / 08 / 2016$.

Paper extracted from the master dissertation of the first author.

${ }^{2}$ Science center and agricultural technology, Universidade Estadual do Norte Fluminense Darcy Ribeiro, Campos dos Goytacazes, RJ, Brazil; karla.rural@yahoo.com.br, flavioufrrj@yahoo.com.br.

${ }^{3}$ Department of animal nutrition and pasture, Universidade Federal Rural do Rio de Janeiro, Seropédica, RJ, Brazil; carloscarvalho_ufrij@yahoo.com.br,malafaia_ufrrj@yahoo.com.br.
} 


\section{INTRODUCTION}

Most pastures in Brazil consist of grasses of the Urochloa genus (Brachiaria genus), which are essential for livestock production because of the low demand for specific soil and weather conditions of its species and cultivars (COSTA; OLIVEIRA; FAQUIN, 2006). The species Urochloa decumbens cv. Basilisk and Urochloa brizantha cv. Marandu, which are considered high-coverage species (FONSECA; MARTUSCELLO, 2010), are highlighted from the Urochloa genus. Urochloa ruziziensis occupies smaller areas of Brazilian land but is reported as having a higher nutritional value than others of the same genus, especially regarding animal nutrition (LIMA et al., 2016). Moreover, this species is also widely used for much tillage systems (ALVES, 2015) and more recently as forage in agropastoral systems. However, the sward structure, morphological composition, forage accumulation and nutritive value of this species when managed under morphophysiological criteria, such as light interception, has not been well studied (TOWNSEND et al., 2013; GOMES et al., 2012).

Fertiliser application at adequate quantities and ratios is essential for achieving higher production and sustainability in grassland environments because the productivity and nutritive value of forage are also affected by soil fertility (FAGUNDES et al., 2005). Many nutrients, from macronutrients to micronutrients, are essential for forage growth and development. However, nitrogen $(\mathrm{N})$ and potassium (K) stand out as highly important nutrients. $\mathrm{N}$ is an essential component of amino acids and proteins, nucleic acids, hormones, and chlorophyll (FAGERIA; CARVALHO, 2014), which are essential organic compounds for plant life, whereas $\mathrm{K}$ is involved in various biochemical reactions necessary for plant metabolism. However, few studies have evaluated the effects of fertilisation with $\mathrm{N}$ and $\mathrm{K}$ on the structural characteristics, production and nutritive value of Urochloa ruziziensis (GOMES et al., 2012; LIMA et al., 2016), which is used in various livestock production systems in Brazil today. Knowledge of the behaviour of these variables can contribute to a better understanding of the morphological and physiological strategies used during its production (growth and development) in each season (TOWNSEND et al., 2013; GOMES et al., 2012).

The aim of this study was to assess the effect of $\mathrm{N}$ and $\mathrm{K}$ fertilisation on the sward structure, forage accumulation and nutritive value of Urochloa ruziziensis managed based on the criterion of light interception during the summer of 2010/2011 season (summer 1); autumn and winter of 2011; and the spring and summer of 2011/2012.

\section{MATERIAL AND METHODS}

The experiment was carried out at the Animal Nutrition and Pastures Department, Animal Science Institute, Universidade Federal Rural do Rio de Janeiro, Seropédica, Rio de Janeiro State (RJ) $\left(22^{\circ}\right.$ $45^{\prime} \mathrm{S}$; $43^{\circ} 41^{\prime} \mathrm{W}$ and $33 \mathrm{~m}$ above sea level) from $12 / 21 / 2010$ to $03 / 30 / 2012$. The following seasons were characterised during this period: summer of $2010 / 2011$ (Sum. 1) $(12 / 21 / 2011$ to $03 / 23 / 2011)$, autumn of 2011 (Aut.) (03/24 to 05/19/2011), spring of 2011 (Spr.) (09/23 to $12 / 21 / 2011)$, and summer of $2011 / 2012$ (Sum. 2) (12/22/2011 to 03/10/2012). The regional climate is AW (Köppen's climate classification) (KOTTEK et al., 2006), with the dry season extending from April to September and the hot and rainy season from October to March.

The means of the weather and water balance data (normal water balance) (THORNTHWAITE; MATHER, 1955) for the experimental period were collected from the website of the Brazilian National Institute of Meteorology and based on data from the agricultural ecology station located in Seropédica (Table 1).

Table 1. Monthly average maximum and minimum temperatures, total rain precipitation and water balance from January 2010 to March 2012 (experimental period).

\begin{tabular}{|c|c|c|c|c|c|}
\hline \multirow{3}{*}{ Month/Year } & \multicolumn{2}{|c|}{ Air Temperature $\left({ }^{\circ} \mathrm{C}\right)$} & \multirow{3}{*}{$\begin{array}{l}\text { Precipitation } \\
(\mathrm{mm})\end{array}$} & \multirow{2}{*}{\multicolumn{2}{|c|}{ Hydric monthly balance $(\mathrm{mm})$}} \\
\hline & \multirow{2}{*}{ Maximum } & \multirow{2}{*}{ Minimum } & & & \\
\hline & & & & Deficit & Excess \\
\hline Dec./2010 & 31.2 & 23.1 & 223.2 & 0.0 & 66.1 \\
\hline Jan./2011 & 33.1 & 23.7 & 120.8 & -40.1 & 0.0 \\
\hline Feb./2011 & 33.5 & 22.0 & 48.2 & -112.0 & 0.0 \\
\hline Mar./2011 & 29.5 & 22.3 & 174.6 & 0.0 & 0.0 \\
\hline Apr./2011 & 29.0 & 19.8 & 102.4 & -4.2 & 0.0 \\
\hline May./2011 & 26.5 & 18.2 & 65.4 & -1.1 & 0.0 \\
\hline Jun./2011 & 23.8 & 14.3 & 39.2 & -3.9 & 0.0 \\
\hline
\end{tabular}

Source: Agroecological station located in Seropédica, Rio de Janeiro State. The following seasons were characterised during this period: summer of 2010/2011 (12/21/2010 to 03/23/2011), autumn of $2011(03 / 24$ to $19 / 05 / 2011)$, spring of $2011(09 / 23$ to $12 / 21 / 2011)$, and summer of $2011 / 2012$ (12/22/2011 to $03 / 10 / 2012)$. 
Table 1. Continuation.

\begin{tabular}{|c|c|c|c|c|c|}
\hline \multirow{3}{*}{ Month/Year } & \multicolumn{2}{|c|}{ Air Temperature $\left({ }^{0} \mathrm{C}\right)$} & \multirow{3}{*}{$\begin{array}{l}\text { Precipitation } \\
\text { (mm) }\end{array}$} & \multirow{2}{*}{\multicolumn{2}{|c|}{ Hydric monthly balance (mm) }} \\
\hline & \multirow{2}{*}{ Maximum } & \multirow{2}{*}{ Minimum } & & & \\
\hline & & & & Deficit & Excess \\
\hline Jul./2011 & 26.4 & 16.6 & 15.0 & -25.6 & 0.0 \\
\hline Aug./2011 & 28.2 & 17.5 & 24.6 & -35.0 & 0.0 \\
\hline Sep./2011 & 18.5 & 11.6 & 14.8 & -22.2 & 0.0 \\
\hline Oct./2011 & 26.9 & 18.6 & 106.8 & 0.0 & 0.0 \\
\hline Nov./2011 & 28.5 & 20.7 & 93.6 & -46.6 & 0.0 \\
\hline Dec./2011 & 33.0 & 25.0 & 234.0 & 0.0 & 0.0 \\
\hline Jan./2012 & 32.3 & 23.4 & 270.0 & 0.0 & 106.3 \\
\hline Feb./2012 & 33.5 & 22.0 & 42.6 & -23.5 & 0.0 \\
\hline Mar./2012 & 31.7 & 21.5 & 0.0 & -88.6 & 0.0 \\
\hline
\end{tabular}

Source: Agroecological station located in Seropédica, Rio de Janeiro State. The following seasons were characterised during this period: summer of 2010/2011 (12/21/2010 to 03/23/2011), autumn of 2011 (03/24 to 19/05/2011), spring of $2011(09 / 23$ to $12 / 21 / 2011)$, and summer of $2011 / 2012(12 / 22 / 2011$ to $03 / 10 / 2012)$.

Soil chemical analyses were performed in January 2011 for samples collected from 0 to $0.1 \mathrm{~m}$ depth, and the results are outlined in Table 2. The application of $100 \mathrm{~kg} \mathrm{ha}^{-1} \mathrm{P}_{2} \mathrm{O}_{5}$ (superphosphate) was performed on 11/23/2011 based on the soil chemical analysis Freire et al. (2013).

Table 2. Results of the soil chemical analysis of the experimental area sampled on 01/17/2011.

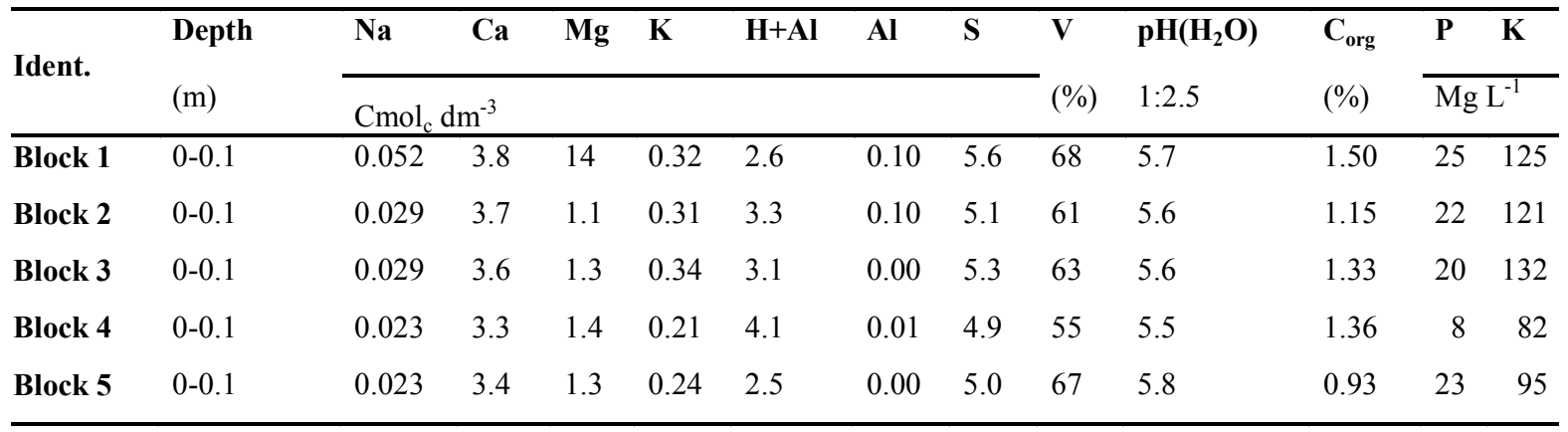

Source: Laboratory of soil, plant and residue analysis (LABFER) of UFRRJ - Seropédica, Rio de Janeiro State.

The species analysed in this study was Urochloa ruziziensis (R. Germ and Evrard). The experimental area consisted of 20 plots of $8 \mathrm{~m}^{2}$ each (experimental unit), distributed in a randomised complete block design due to small differences in soil fertility and the slope of the area between the blocks. The plots were standardised by cutting at a height of $0.1 \mathrm{~m}$ from the ground in the spring $(11 / 10 / 2010)$.

The treatments consisted of one control treatment (without fertilisation) and three fertilisation levels $\left(120,240\right.$ and $360 \mathrm{~kg} \mathrm{ha}^{-1}$ year $^{-1} \mathrm{~N}$ as urea and 120, 240 and $360 \mathrm{~kg} \mathrm{ha}^{-1}$ year $^{-1} \mathrm{~K}_{2} \mathrm{O}$ as potassium chloride) that were divided into five applications per year, with 24, 48 and $72 \mathrm{~kg} \mathrm{ha}^{-1} \mathrm{~N}$ and 24,48 and $72 \mathrm{~kg} \mathrm{ha}^{-1} \mathrm{~K}_{2} \mathrm{O}$ applied per plot. The applications were divided as follows: three in the summer, one in the fall and two in the spring. The same process was carried out after the rain, in order to reduce losses of nitrogen through volatilisation since it was not used during the irrigation evaluation period.

Cutting was performed manually and set according to the interception of photosynthetically active radiation $(95 \% \mathrm{LI})$ using a sward analyser (AccuPAR Linear PAR/LAI Ceptometer, Model PAR - 80). Twelve readings above and below the forage sward were simultaneously recorded to determine the LI. The criterion established for the cut of all treatments (95\% LI) was not met by the non-fertilisation treatment (T0) because of the high forage production seasonality and slower growth in autumn. Thus, this treatment was not cut in autumn, and only a comparison of the means with the other treatments in the same season was performed.

The forage sward heights (SW) were measured on the same dates of LI readings, with 20 measurements per experimental unit based on the curvature of the last fully expanded leaves as reported by Carnevalli et al. (2006) using a ruler.

Forage was collected $0.1 \mathrm{~m}$ from the soil surface within $2.0 \mathrm{~m}^{2}$ of useful area in the plots, and $6 \mathrm{~m}^{2}$ of the border was discarded when cutting in each plot. The green material was collected and weighed, and the samples were stored in labelled plastic bags and subsequently separated into two 
subsamples of approximately $1 \mathrm{~kg}$ each. Subsample 1 was separated into dead material, pseudostem (stem + leaf sheath) and leaf blade, and subsample 2 was separated into dead material and green material. All of the fractions were dried in a ventilated oven at $55^{\circ} \mathrm{C}$ for 72 hours to assess their respective dry matter contents. The morphological composition was expressed as a leaf blade dry mass (LBDM), stem dry mass (SDM) and dead material dry mass (DMDM) percentage of the forage mass, and the leaf blade: stem ratio (LBSR) was estimated based on the values of the quotients assessed between the LBDM and SDM data. The forage accumulation rates (FAR) were estimated according to the quotient assessed between the sums of the forage mass and the period encompassing all cuts performed for each treatment in each season. The forage bulk densities were estimated based on the values of the quotients assessed between the forage mass and their respective mean sward height.

Subsample 2 (green material) was used to analyse the forage nutritive value after drying in a ventilated oven at $55^{\circ} \mathrm{C}$ for 72 hours. These samples were processed in mill through a $1.0 \mathrm{~mm}$ mesh. The dry matter (DM) and crude protein $(\mathrm{CP})$ contents were estimated according to Silva and Queiroz (2002). The neutral detergent fibre (NDF), acid detergent fibre (ADF) and lignin (LIG) contents, and the neutral detergent insoluble protein (NDIP) and acid detergent insoluble protein (ADIP) contents were estimated according to the methods by Van Soest, Robertson and Lewis (1991) and Malafaia and Vieira (1997), respectively. The in vitro dry matter digestibility (IVDMD) was estimated using the method by Tilley and Terry (1963) modified by
Moore and Mott (1974).

A complete randomised block design with four treatments and five replicates was used under a repeated time model measures during the summer of 2010/2011 (summer 1), autumn and winter of 2011, and spring and summer of 2011/2012. The data were subjected to an analysis of variance (ANOVA) using the PROC MIXED procedure in SAS ${ }^{\circledR}$ (Statistical Analysis System) version 9.0 for Windows with repeated measures. The Akaike information criterion was used to select the variance and covariance matrix (WOLFINGER , 1993), and the effects of the main causes of variation could be detected as follows: the levels of $\mathrm{N}$ and $\mathrm{K}_{2} \mathrm{O}$ and season and their interactions were considered fixed effects, and the effects of blocks and their interactions were considered random effects. The means of the treatments were estimated using a least-squares means (LSMEANS) statement, and comparisons between means (when necessary) were performed using the probability of difference (PDIFF) procedure. Regression analyses were performed using the regression procedure of the PROC REG of $\mathrm{SAS}^{\circledR}$. The $\alpha 0.05$ probability level was used in all significance tests.

\section{RESULTS AND DISCUSSION}

There was an effect of the fertilisation levels and season interaction on sward height, forage mass, forage bulk density, forage accumulation rate (Table 3 ), and leaf blade:stem ratio and the percentages of leaf blade dry matter, steam dry matter and dead material dry matter (Table 4).

Table 3. Sward height (SW), forage mass (FM), forage bulk density (FBD) and forage accumulation rate (FAR) of Urochloa ruziziensis as a function of nitrogen and potassium fertilisation levels and seasons.

\begin{tabular}{|c|c|c|c|c|c|c|c|c|}
\hline \multirow{2}{*}{ Season } & \multicolumn{4}{|c|}{$\mathrm{N}$ and $\mathrm{K}_{2} \mathrm{O}$ levels $\left(\mathrm{kg} \mathrm{ha}^{-1}\right.$ year $\left.^{-1}\right)$} & \multirow{2}{*}{ SEM } & \multirow{2}{*}{ Equation } & \multirow{2}{*}{$\mathrm{P}$} & \multirow{2}{*}{$\mathrm{R}^{2}$} \\
\hline & 0 & 120 & 240 & 360 & & & & \\
\hline \multicolumn{9}{|c|}{ SW (cm) } \\
\hline Sum. 1 & $57^{C}$ & $56^{\mathrm{C}}$ & $54^{\mathrm{C}}$ & $46^{\mathrm{C}}$ & 3.4 & $\hat{\mathrm{Y}}=53$ & ${ }^{\mathrm{l}} \mathrm{NS}$ & - \\
\hline Aut. & - & $38^{\mathrm{bD}}$ & $38^{\mathrm{bD}}$ & $49^{\mathrm{aC}}$ & 2.1 & - & - & - \\
\hline Spr. & $68^{\mathrm{B}}$ & $67^{\mathrm{B}}$ & $66^{\mathrm{B}}$ & $66^{\mathrm{B}}$ & 3.7 & $\hat{Y}=67$ & NS & - \\
\hline Sum. 2 & $75^{\mathrm{A}}$ & $86^{\mathrm{A}}$ & $94^{\mathrm{A}}$ & $75^{\mathrm{A}}$ & 2.6 & $\hat{Y}=73.62+0.196 X-0.0005 X^{2}$ & 0.0002 & 0.63 \\
\hline \multicolumn{9}{|c|}{ FM $\left(\mathrm{kg} \mathrm{ha}^{-1}\right)$} \\
\hline Sum. 1 & $2413^{\mathrm{C}}$ & $3245^{\mathrm{C}}$ & $3520^{\mathrm{B}}$ & $2987^{\mathrm{C}}$ & 256.6 & $\hat{\mathrm{Y}}=3041$ & 0.0087 & 0.43 \\
\hline Aut. & - & $830^{\mathrm{aD}}$ & $755^{\mathrm{bC}}$ & $663^{\mathrm{cD}}$ & 95.9 & - & - & - \\
\hline Spr. & $4522^{\mathrm{A}}$ & $6195^{\mathrm{A}}$ & $4238^{\mathrm{B}}$ & $4544^{\mathrm{B}}$ & 345.4 & $\hat{Y}=4875$ & NS & - \\
\hline Sum. 2 & $3874^{\mathrm{B}}$ & $4714^{\mathrm{B}}$ & $7299^{\mathrm{A}}$ & $6494^{\mathrm{A}}$ & 415.3 & $\hat{Y}=4233+7.9483 X$ & 0.0016 & 0.43 \\
\hline \multicolumn{9}{|c|}{ FBD $\left(\mathrm{kg} \mathrm{cm}^{-1} \mathrm{ha}^{-1}\right)$} \\
\hline Sum. 1 & $62^{\mathrm{AB}}$ & $59^{\mathrm{B}}$ & $67^{\mathrm{B}}$ & $63^{\mathrm{B}}$ & 4.6 & $\hat{\mathrm{Y}}=63$ & ${ }^{1} \mathrm{NS}$ & - \\
\hline Aut. & - & $22^{\mathrm{aC}}$ & $19^{\mathrm{aC}}$ & $12^{\mathrm{bC}}$ & 2.2 & - & - & - \\
\hline Spr. & $68^{\mathrm{A}}$ & $96^{\mathrm{A}}$ & $63^{\mathrm{B}}$ & $68^{\mathrm{B}}$ & 4.2 & $\hat{Y}=74$ & NS & - \\
\hline Sum. 2 & $53^{\mathrm{B}}$ & $57^{\mathrm{B}}$ & $80^{\mathrm{A}}$ & $84^{\mathrm{A}}$ & 3.4 & $\hat{Y}=50.93+0.0972 X$ & $<0.0001$ & 0.63 \\
\hline \multicolumn{9}{|c|}{ FAR $\left(\mathrm{kg} \mathrm{ha}^{-1}\right.$ day $\left.^{-1}\right)$} \\
\hline Sum. 1 & $54^{\mathrm{A}}$ & $54^{\mathrm{B}}$ & $59^{\mathrm{A}}$ & $68^{\mathrm{B}}$ & 4.0 & $\hat{\mathrm{Y}}=51.31+0.040853 \mathrm{X}$ & 0.0197 & 0.27 \\
\hline
\end{tabular}

Means followed by different lowercase and uppercase letters in the same row and column, respectively, are significantly different $(\mathrm{P}<0.05)$ according to Student's t-test (PDIFF). SEM=standard error of the mean. $\mathrm{P}$ : equation regression significant. $\mathrm{R}^{2}$ : determination coefficient. 
Table 3. Continuation.

\begin{tabular}{|c|c|c|c|c|c|c|c|c|}
\hline \multirow{2}{*}{ Season } & \multicolumn{4}{|c|}{$\mathrm{N}$ and $\mathrm{K}_{2} \mathrm{O}$ levels $\left(\mathrm{kg} \mathrm{ha}^{-1}\right.$ year $\left.^{-1}\right)$} & \multirow{2}{*}{ SEM } & \multirow{2}{*}{ Equation } & \multirow{2}{*}{$\mathrm{P}$} & \multirow{2}{*}{$\mathrm{R}^{2}$} \\
\hline & 0 & 120 & 240 & 360 & & & & \\
\hline \multicolumn{9}{|c|}{ FAR $\left(\mathrm{kg} \mathrm{ha}^{-1}\right.$ day $\left.^{-1}\right)$} \\
\hline Aut. & - & $15^{\mathrm{aC}}$ & $13^{\mathrm{abB}}$ & $11^{\mathrm{bC}}$ & 3.5 & - & - & - \\
\hline Spr. & $50^{\mathrm{A}}$ & $90^{\mathrm{A}}$ & $66^{\mathrm{A}}$ & $78^{\mathrm{B}}$ & 3.7 & $\hat{Y}=54.74+0.2245 X-0.0005 X^{2}$ & 0.0470 & 0.30 \\
\hline Sum. 2 & $5291^{\mathrm{B}}$ & $5248^{\mathrm{B}}$ & $7502^{\mathrm{AB}}$ & $11383^{\mathrm{A}}$ & 571 & $\hat{\mathrm{Y}}=4276.6+17,109 \mathrm{X}$ & $<0.0001$ & 0.67 \\
\hline
\end{tabular}

Means followed by different lowercase and uppercase letters in the same row and column, respectively, are significantly different $(\mathrm{P}<0.05)$ according to Student's t-test $(\mathrm{PDIFF})$. SEM=standard error of the mean. P: equation regression significant. $\mathrm{R}^{2}$ : determination coefficient.

The sward height of $U$. ruziziensis was lower in autumn except for in the treatment with the highest levels $\left(360 \mathrm{~kg} \mathrm{ha}^{-1} \mathrm{~N}\right.$ and $\left.\mathrm{K}_{2} \mathrm{O}\right)$, which showed a similar value to that of summer $1(46 \mathrm{~cm})$. The lower height observed in autumn results from unfavourable environmental conditions caused by the low availability of growth factors (water, light and temperature), as shown in Table 1. The same was observed by Maranhão (2008) when studying $U$. decumbens cv. Basilisk under two levels of $\mathrm{N}(0$ and $\left.200 \mathrm{~kg} \mathrm{ha}^{-1}\right)$ and five cutting periods $(21,28,35,42$, and 49 days) in autumn. No significant fertilisation effect on sward height was observed in the regression analyses in summer and spring 2010/2011, which presented mean values of 53 and $67 \mathrm{~cm}$, respectively, and corroborated the hypothesis of Da Silva (2009) regarding the limited effect exerted by management factors, including fertilisation, on sward structural characteristics when managed under morphophysiological criteria, including light interception. However, this variable fit a quadratic regression model in the summer of $2011 / 2012$, with an estimated maximum height of 93 $\mathrm{cm}$ corresponding to a fertilisation rate of $196 \mathrm{~kg} \mathrm{ha}^{-1}$ $\mathrm{N}$ and $\mathrm{K}_{2} \mathrm{O}$. This difference in performance in the summer may result from the flowering of plants in the 0 and $360 \mathrm{~kg} \mathrm{ha}^{-1} \mathrm{~N}$ and $\mathrm{K}_{2} \mathrm{O}$ treatments promoting the cessation of forage growth starting at this phenological stage.

Forage mass decreased with increased fertilisation levels in autumn, which may have resulted from the effects of water deficits (Table 1) concomitant with the increasing amounts of fertiliser, which may have impaired the growth and development of plants due to the salting effect, as asserted by (LIMA et al., 2016). The forage mass data did not fit a specific regression model in the summer and spring of 2010/2011, and mean values of 3041 and $4875 \mathrm{~kg} \mathrm{ha}^{-1}$, respectively, were observed (Table 3). However, in the summer of 2011/2012, forage mass responded linearly and positively to increases of fertiliser level, possibly due to the high rainfall observed in January 2012, contributing to the better use of fertiliser. These results corroborate the findings by Magalhães et al. (2007), who noted an increase in forage mass with increases in $\mathrm{N}$ levels $\left(0,100,200\right.$ and $\left.300 \mathrm{~kg} \mathrm{ha}^{-1}\right)$ when studying $U$. decumbens.

Smaller forage bulk density values were observed in autumn and may have been caused by the low forage mass combined with the lower observed tiller population densities. This variable did not fit a specific regression model in the summer and spring of 2010/2011, and mean values of 63 and $74 \mathrm{~kg} \mathrm{~cm}^{-1} \mathrm{ha}^{-1}$, respectively, were recorded (Table $3)$. In contrast, a linear and positive response to the increase in fertiliser levels was observed in the summer of 2011/2012, and a similar increase was observed for forage mass. However, a decrease in the value of this variable was observed with increased fertiliser levels in autumn, which may be explained by the low water availability observed in autumn (Table 1), reducing the effectiveness of the applied fertiliser, especially at higher amounts. The forage bulk density values recorded in this study are below those reported in the literature for $U$. decumbens, which showed mean values of $226 \mathrm{~kg} \mathrm{~cm}^{-1} \mathrm{ha}^{-1} \mathrm{DM}$ and ranges of 98.7 to $284.4 \mathrm{~kg} \mathrm{~cm}^{-1} \mathrm{ha}^{-1} \mathrm{DM}$ for $\mathrm{N}$ levels from 75 to $300 \mathrm{~kg} \mathrm{ha}^{-1}$ (FAGUNDES et al., 2006), as well as for other forage species, including bermuda grass (Cynodon spp.), which showed a maximum value of $290 \mathrm{~kg} \mathrm{~cm} \mathrm{ha}^{-1} \mathrm{DM}$ (CARNEVALLI et al., 2001).

The forage accumulation rate responded linearly and positively to the increase in fertiliser levels in the summer of 2010/2011 and 2011/2012 and quadratically and positively to the increase in fertiliser levels in the spring, with an estimated maximum value of $80 \mathrm{~kg} \mathrm{ha}^{-}$day $^{-1}$ for the $224 \mathrm{~kg} \mathrm{ha}^{-1}$ $\mathrm{N}$ and $\mathrm{K}_{2} \mathrm{O}$ treatment (Table 3 ). The values of this variable decreased with increased fertiliser levels applied in autumn; this decrease was most likely caused by the water deficit (Table 1) and increased fertiliser levels, which may have affected the forage accumulation. The results recorded in the present study for both summer seasons are similar to those reported by Moreira et al. (2009), who also observed a linear, positive effect with increased applied fertiliser in a study of $U$. decumbens fertilised with four $\mathrm{N}$ levels $\left(75,150,225\right.$ and $300 \mathrm{~kg} \mathrm{ha}^{-1}$ year $\left.^{-1}\right)$.

Greater percentages of leaf blade dry matter and lower percentages of stem dry matter were observed in autumn compared with other seasons because of the reduced plant growth in that season resulting from unfavourable environmental conditions (Table 1), and autumn was also characterised by presented lower sward height (Table 4). 
Table 4. Percentages of leaf blade dry mass (LBDM), stem dry mass (SDM) and dead material dry mass (DMDM) and the leaf blade: stem ratio (LBSR) of Urochloa ruziziensis as a function of nitrogen and potassium fertilisation levels and seasons.

\begin{tabular}{|c|c|c|c|c|c|c|c|c|}
\hline \multirow{2}{*}{ Seas. } & \multicolumn{4}{|c|}{$\mathrm{N}$ and $\mathrm{K}_{2} \mathrm{O}$ levels $\left(\mathrm{kg} \mathrm{ha}^{-1}\right.$ year $\left.^{-1}\right)$} & \multirow{2}{*}{ SEM } & \multirow{2}{*}{ Equation } & \multirow{2}{*}{$\mathrm{P}$} & \multirow{2}{*}{$\mathrm{R}^{2}$} \\
\hline & 0 & 120 & 240 & 360 & & & & \\
\hline \multicolumn{9}{|c|}{ LBDM (g kg-1) } \\
\hline Sum. 1 & $51.2^{\mathrm{A}}$ & $43.3^{B}$ & $44.2^{\mathrm{B}}$ & $55.0^{\mathrm{B}}$ & 1.8 & $\hat{Y}=51.31-0.1057 X+0.0003 X^{2}$ & 0.0002 & 0.63 \\
\hline Aut. & - & $52.7^{\mathrm{bA}}$ & $55.0^{\mathrm{bA}}$ & $64.0^{\mathrm{aA}}$ & 1.8 & - & - & - \\
\hline Spr. & $35.3^{\mathrm{B}}$ & $42.6^{\mathrm{B}}$ & $45.3^{\mathrm{B}}$ & $47.8^{\mathrm{C}}$ & 2.0 & $\hat{Y}=37.76+0.0305 X$ & 0.0010 & 0.46 \\
\hline Sum. 2 & $25.0^{\mathrm{C}}$ & $32.6^{\mathrm{C}}$ & $19.4^{\mathrm{C}}$ & $38.5^{\mathrm{D}}$ & 1.8 & $\hat{\mathrm{Y}}=28.9$ & ${ }^{1} \mathrm{NS}$ & - \\
\hline \multicolumn{9}{|c|}{ SDM $\left(\mathrm{g} \mathrm{kg}^{-1}\right)$} \\
\hline Sum. 1 & $44.0^{\mathrm{C}}$ & $50.2^{\mathrm{B}}$ & $48.7^{\mathrm{B}}$ & $40.1^{\mathrm{B}}$ & 1.8 & $\hat{Y}=44.47+0.0647 X-0.0002 X^{2}$ & 0.0184 & 0.37 \\
\hline Aut. & - & $39.6^{\mathrm{aC}}$ & $40.0^{\mathrm{aC}}$ & $31.0^{\mathrm{bC}}$ & 1.1 & - & - & - \\
\hline Spr. & $53.7^{\mathrm{B}}$ & $46.2^{\mathrm{CB}}$ & $45.2^{\mathrm{B}}$ & $42.0^{\mathrm{B}}$ & 1.8 & $\hat{\mathrm{Y}}=52.1-0.0275 \mathrm{X}$ & 0.0012 & 0.45 \\
\hline Sum. 2 & $67.0^{\mathrm{A}}$ & $59.2^{\mathrm{A}}$ & $59.6^{\mathrm{A}}$ & $51.2^{\mathrm{A}}$ & 2.4 & $\hat{Y}=66.07-0.0298 X$ & $<0.0001$ & 0.60 \\
\hline \multicolumn{9}{|c|}{ DMDM $\left(\mathrm{g} \mathrm{kg}^{-1}\right)$} \\
\hline Sum. 1 & $4.8^{\mathrm{C}}$ & $6.5^{\mathrm{B}}$ & $7.1^{\mathrm{C}}$ & $5.0^{\mathrm{B}}$ & 0.5 & $\hat{\mathrm{Y}}=4.79+0.0266 \mathrm{X}-0.0001 \mathrm{X}^{2}$ & 0.0196 & 0.48 \\
\hline Aut. & - & $7.7^{\mathrm{aB}}$ & $5.0^{\mathrm{bD}}$ & $5.1^{\mathrm{bB}}$ & 0.6 & - & - & - \\
\hline Spr. & $11.0^{\mathrm{A}}$ & $11.2^{\mathrm{A}}$ & $10.0^{\mathrm{B}}$ & $10.3^{\mathrm{A}}$ & 0.5 & $\hat{Y}=10,6$ & NS & - \\
\hline Sum. 2 & $8.0^{\mathrm{B}}$ & $8.2^{\mathrm{C}}$ & $21.0^{\mathrm{A}}$ & $10.4^{\mathrm{A}}$ & 0.7 & $\hat{\mathrm{Y}}=11.9$ & NS & - \\
\hline \multicolumn{9}{|l|}{ LBSR } \\
\hline Sum. 1 & $1.2^{\mathrm{A}}$ & $0.9^{\mathrm{B}}$ & $0.9^{\mathrm{B}}$ & $1.4^{\mathrm{B}}$ & & $\hat{\mathrm{Y}}=1.24-0.0044 \mathrm{X}+0.0000138 \mathrm{X}^{2}$ & 0.0121 & 0.40 \\
\hline Aut. & - & $1.3^{\mathrm{bA}}$ & $1.4^{\mathrm{bA}}$ & $2.1^{\mathrm{aA}}$ & & - & - & - \\
\hline Spr. & $0.6^{\mathrm{BC}}$ & $0.9^{\mathrm{B}}$ & $1.0^{\mathrm{B}}$ & $1.1^{\mathrm{C}}$ & 0.1 & $\hat{\mathrm{Y}}=0.73+0.0012 \mathrm{X}$ & 0.0004 & 0.51 \\
\hline Sum. 2 & $0.4^{\mathrm{C}}$ & $0.6^{\mathrm{C}}$ & $0.3^{\mathrm{C}}$ & $0.9^{\mathrm{D}}$ & & $\hat{\mathrm{Y}}=0.55$ & NS & - \\
\hline
\end{tabular}

Means followed by different lowercase and uppercase letters in the same row and column, respectively, are significantly different $(\mathrm{P}<0.05)$ according to Student's t-test (PDIFF). SEM=standard error of the mean. $\mathrm{P}$ : equation regression significant. $\mathrm{R}^{2}$ : determination coefficient.

The data from summer 2010/2011 fit positive and negative quadratic regression models as a function of fertilisation, with minimum and maximum values of 42.0 and $49.7 \mathrm{~g} \mathrm{~kg}^{-1}$ obtained upon fertilisation with 176 and $161 \mathrm{~kg} \mathrm{ha}^{-1}$ and $\mathrm{N}$ and $\mathrm{K}_{2} \mathrm{O}$ for the percentages of leaf blade and stem dry matter, respectively. A positive, linear response was observed for the leaf blade dry matter percentage in the spring. However, this variable did not fit a specific regression model with a mean value of $28.9 \mathrm{~g} \mathrm{~kg}^{-1}$ in the summer of $2011 / 2012$, whereas the of stem dry matter percentage responded a linear and negative model in the spring and summer of $2011 / 2012$. Therefore, the leaf blade dry matter percentage increased in the autumn and spring, and the percentage of stem dry matter values decreased in the spring and summer. Higher values of dead material dry matter percentages were observed in the spring, except for in the treatment with $240 \mathrm{~kg} \mathrm{ha}^{-1} \mathrm{~N}$ and $\mathrm{K}_{2} \mathrm{O}$, which showed a higher value in the summer of $2011 / 2012$. This variable assessed in the summer of $2011 / 2012$ for the $240 \mathrm{~kg} \mathrm{ha}^{-1}$ treatment may have resulted from lodging caused by the increased plant height in that treatment (Table 4) and from intense rainfall, especially in December and January (Table 1). A significant quadratic and positive effect of the dead material dry matter percentage was observed in the summer of $2010 / 2011$, presenting an estimated maximum value of $6.5 \mathrm{~g} \mathrm{~kg}^{-1}$ assessed at a level of $133 \mathrm{~kg} \mathrm{ha}^{-1} \mathrm{~N}$ and $\mathrm{K}_{2} \mathrm{O}$. However, no significant effect was observed in the spring and summer of 2011/2012 under a specific regression model, and mean values of 10.6 and $11.9 \mathrm{~g} \mathrm{~kg}^{-1}$, respectively, were recorded. A decrease in these variables was observed in autumn when the fertilisation levels increased. In general, the assessed values of the dead material dry matter percentages (even the highest value of $21 \mathrm{~g} \mathrm{~kg}^{-1}$ for $240 \mathrm{~kg} \mathrm{ha}^{-1}$ in the summer of 2011/2012) may be considered low compared with other cutting criteria (chronological).

The leaf blade: stem ratio was higher in autumn and in the control treatment in the summer of 2010/2011. The higher values in autumn may have resulted from less favourable environmental conditions (Table 1), which caused less stem elongation and growth than those of the leaf blades. A quadratic negative effect was observed in the summer of 2010/2011, with an estimated minimum LBSR of 0.18 for the levels of $160 \mathrm{~kg} \mathrm{ha}^{-1} \mathrm{~N}$ and $\mathrm{K}_{2} \mathrm{O}$, and a linear positive effect was observed in the spring. This variable did not fit a specific regression model in the summer of 2011/2012, and a mean value of 0.5 was observed. The values assessed in this experiment in the summer of 2010/2011 and the spring and summer of 2011/2012 were mostly below the level considered critical (1.0) according to Lima et al. (2006) and Johnson et al. (2001); thus, this grass species was characterised as a low leaf blade: stem ratio plant in the season of greater vegetative growth. Although $U$. ruziziensis showed a higher value of this variable in autumn, this relationship could not offset its lower production capacity because of its marked forage production seasonality (assessed based on forage accumulation rate; 
Table 3), which resulted in lower leaf blade: stem ratio values in this season.

A significant effect of the interaction between fertilisation levels and season was observed on the dry matter, crude protein, neutral detergent fibre, acid detergent fibre, lignin, neutral detergent insoluble protein, acid detergent insoluble protein contents and on the in vitro dry matter digestibility (Tables 5 and 6).

Table 5. Contents of dry matter (DM), crude protein (CP) and in vitro dry matter digestibility (IVDMD) of Urochloa ruziziensis as a function of nitrogen and potassium fertilisation levels and seasons.

\begin{tabular}{|c|c|c|c|c|c|c|c|c|}
\hline \multirow{2}{*}{ Seas. } & \multicolumn{4}{|c|}{$\mathrm{N}$ and $\mathrm{K}_{2} \mathrm{O}$ levels $\left(\mathrm{kg} \mathrm{ha}^{-1}\right.$ year $\left.^{-1}\right)$} & \multirow{2}{*}{ SEM } & \multirow{2}{*}{ Equation } & \multirow{2}{*}{$\mathrm{P}$} & \multirow{2}{*}{$\mathrm{R}^{2}$} \\
\hline & 0 & 120 & 240 & 360 & & & & \\
\hline \multicolumn{9}{|c|}{ DM $\left(\mathrm{g} \mathrm{kg}^{-1} \mathrm{DM}\right)$} \\
\hline Sum. 1 & $18.6^{\mathrm{B}}$ & $15.6^{\mathrm{C}}$ & $16.2^{\mathrm{B}}$ & $13.9^{\mathrm{B}}$ & 1.0 & $\hat{\mathrm{Y}}=16.1$ & ${ }^{\mathrm{T}} \mathrm{NS}$ & - \\
\hline Aut. & - & $16.9^{\mathrm{aC}}$ & $17.1^{\mathrm{aB}}$ & $15.0^{\mathrm{bB}}$ & 0.3 & - & - & - \\
\hline Spr. & $18.2^{\mathrm{B}}$ & $18.0^{\mathrm{B}}$ & $17.1^{\mathrm{B}}$ & $15.5^{\mathrm{B}}$ & 0.4 & $\hat{Y}=19.09-0.009 X$ & $<0.0001$ & 0.71 \\
\hline Sum. 2 & $23.9^{\mathrm{A}}$ & $21.7^{\mathrm{A}}$ & $20.7^{\mathrm{A}}$ & $19.7^{\mathrm{A}}$ & 0.5 & $\hat{Y}=23.53-0.0113 X$ & $<0.0001$ & 0.66 \\
\hline \multicolumn{9}{|c|}{$\mathrm{CP}\left(\mathrm{g} \mathrm{kg}^{-1} \mathrm{DM}\right)$} \\
\hline Sum. 1 & $7.8^{\mathrm{A}}$ & $12.8^{\mathrm{A}}$ & $6.1^{\mathrm{B}}$ & $9.8^{\mathrm{B}}$ & & $\hat{\mathrm{Y}}=9.1$ & NS & - \\
\hline Aut. & - & $7.9^{\mathrm{bB}}$ & $8.7^{\mathrm{bA}}$ & $11.2^{\mathrm{aA}}$ & & - & - & - \\
\hline Spr. & $4.8^{\mathrm{B}}$ & $7.2^{\mathrm{BC}}$ & $8.3^{\mathrm{A}}$ & $11.7^{\mathrm{A}}$ & 0.3 & $\hat{\mathrm{Y}}=4.75+0.0182 \mathrm{X}$ & $<0.0001$ & 0.85 \\
\hline Sum. 2 & $4.9^{\mathrm{B}}$ & $6.9^{\mathrm{C}}$ & $8.1^{\mathrm{A}}$ & $9.7^{\mathrm{B}}$ & & $\hat{\mathrm{Y}}=5.08+0.0128 \mathrm{X}$ & $<0.0001$ & 0.84 \\
\hline \multicolumn{9}{|c|}{ IVDMD (\%) } \\
\hline Sum. 1 & $66.6^{\mathrm{A}}$ & $67.8^{\mathrm{A}}$ & $66.3^{\mathrm{B}}$ & $69.7^{\mathrm{A}}$ & & $\hat{Y}=66.45+0.0064 X$ & 0.0519 & 0.19 \\
\hline Aut. & - & $61.8^{\mathrm{bA}}$ & $65.7^{\mathrm{aB}}$ & $66.9^{\mathrm{aB}}$ & & & - & - \\
\hline Spr. & $58.2^{\mathrm{B}}$ & $64.6^{\mathrm{B}}$ & $68.7^{\mathrm{A}}$ & $67.5^{\mathrm{B}}$ & 0.7 & $\hat{Y}=59.92-0.0269 X$ & $<0.0001$ & 0.66 \\
\hline Sum. 2 & $57.9^{\mathrm{B}}$ & $58.9^{\mathrm{D}}$ & $52.0^{\mathrm{C}}$ & $59.1^{\mathrm{C}}$ & & $\hat{\mathrm{Y}}=56.9$ & NS & - \\
\hline
\end{tabular}

Means followed by different lowercase and uppercase letters in the same row and column, respectively, are significantly different $(\mathrm{P}<0.05)$ according to Student's t-test (PDIFF). SEM=standard error of the mean. $\mathrm{P}$ : equation regression significant. $\mathrm{R}^{2}$ : determination coefficient.

Higher dry matter values were assessed in the summer of 2011/2012. A linear negative effect on this variable was observed in the spring and summer of 2011/2012 (Sum. 2) but did not fit a specific regression model, and a mean value of $16 \mathrm{~g} \mathrm{~kg}^{-1} \mathrm{DM}$ was recorded in the summer of 2010/2011 (Sum. 1). The reduced contents in the spring and in Sum. 2 may be explained by the younger age at cutting in the 360, 240, 120 and $0 \mathrm{~kg} \mathrm{ha}^{-1} \mathrm{~N}$ and $\mathrm{K}_{2} \mathrm{O}$ treatments, which provided forage with a higher moisture level. Sousa et al. (2010) also observed a linear reduction in the dry matter content with increased $\mathrm{N}$ fertilisation in a study of Tanzania grass (Panicum maximum cv. Tanzania) fertilised with $\mathrm{N}$ $\left(0,100,200\right.$ and $300 \mathrm{~kg} \mathrm{ha}^{-1}$ year $\left.^{-1}\right)$ and phosphorus $\left(0,50\right.$ and $100 \mathrm{~kg} \mathrm{ha}^{-1}$ year $\left.^{-1}\right)$.

The crude protein content was higher in the summer of 2010/2011 in the control and $120 \mathrm{~kg} \mathrm{ha}^{-1}$ $\mathrm{N}$ and $\mathrm{K}_{2} \mathrm{O}$ treatment, although the treatments with the highest levels of fertiliser (240 and $360 \mathrm{~kg} \mathrm{ha}^{-1} \mathrm{~N}$ and $\mathrm{K}_{2} \mathrm{O}$ ) showed the highest values in the autumn, spring and summer 2011/2012. This variable did not fit a specific regression model in the summer of $2010 / 2011$, and a mean value of $16.1 \mathrm{~g} \mathrm{~kg}^{-1}$ was recorded, which may have resulted from the marked water deficit observed in Sum. 1 (Table 1). The dry matter values fit a positive linear model in the spring and summer of 2011/2012 because of the beneficial effect of $\mathrm{N}$ and $\mathrm{K}$ fertilisation resulting from the strong effect of $\mathrm{N}$ and $\mathrm{K}$ on forage plant growth and the controlled emergence of new organs in plants, which consist of $\mathrm{N}$ rich compounds, including proteins, chlorophyll, amino acids and peptides (FAGERIA; CARVALHO, 2014). These results are similar to the findings of Costa, Oliveira and Faquin (2006) in a study of $U$. brizantha $\mathrm{cv}$. MG5 with $\mathrm{N}(0$, 50,100 and $\left.200 \mathrm{~kg} \mathrm{ha}^{-1}\right)$ and $\mathrm{K}(0,50,100$ and 200 $\mathrm{kg} \mathrm{ha}^{-1}$ ) fertilisation.

A positive linear effect on the in vitro dry matter digestibility was observed with increased fertiliser levels in the summer and spring of $2010 / 2011$ and at the highest levels $\left(360 \mathrm{~kg} \mathrm{ha}^{-1}\right.$ of $\mathrm{N}$ and $\mathrm{K}_{2} \mathrm{O}$ ) in the autumn and summer of 2011/2012, showing that this variable responded to the increased levels of $\mathrm{N}$ and $\mathrm{K}$ fertilisation used in this study under all of the assessed seasons, except for in Sum. 2 , in which there was no effect of the $\mathrm{N}$ and $\mathrm{K}$ levels, with a $56.9 \%$ average. The increase in this variable with $\mathrm{N}$ and $\mathrm{K}$ fertilisation coincides with the corresponding reduction in NDF contents (Table 6). These results are similar to the results of Corrêa et al. (2007), who observed an increase in IVDMD with increasing $\mathrm{N}$ levels in Bermuda grass subjected to two sources (urea and ammonium nitrate) and five levels $\left(0,25,50,100,200 \mathrm{~kg} \mathrm{~N}^{-1}\right.$ cut $\left.^{-1}\right)$ of $\mathrm{N}$.

Except for the treatment with the highest fertiliser levels $\left(360 \mathrm{~kg} \mathrm{ha}^{-1}\right.$ of $\mathrm{N}$ and $\left.\mathrm{K}_{2} \mathrm{O}\right)$, which had higher neutral detergent fibre values in the summer and autumn of 2010/2011, the highest values were obtained in the summer of 2011/2012 for all of the other treatments (Table 6) 
Table 6. Neutral detergent fibre (NDF), lignin (LIG), N associated with NDF (neutral detergent insoluble protein, NDIP) and $\mathrm{N}$ associated with ADF (acid detergent insoluble protein, ADIP) of Urochloa ruziziensis as a function of nitrogen and potassium fertilisation levels and seasons.

\begin{tabular}{|c|c|c|c|c|c|c|c|c|}
\hline \multirow{2}{*}{ Seas. } & \multicolumn{4}{|c|}{$\mathrm{N}$ and $\mathrm{K}_{2} \mathrm{O}$ levels $\left(\mathrm{kg} \mathrm{ha}^{-1}\right.$ year $\left.^{-1}\right)$} & \multirow{2}{*}{ SEM } & \multirow{2}{*}{ Equation } & \multirow{2}{*}{$P$} & \multirow{2}{*}{$\mathrm{R}^{2}$} \\
\hline & 0 & 120 & 240 & 360 & & & & \\
\hline \multicolumn{9}{|c|}{ NDF (g kg ${ }^{-1}$ DM) } \\
\hline Sum. 1 & $63.5^{\mathrm{C}}$ & $65.9^{\mathrm{B}}$ & $65.5^{\mathrm{B}}$ & $60.5^{\mathrm{A}}$ & \multirow{4}{*}{0.9} & $\hat{Y}=63.43+0.0379 X-0.0001 X^{2}$ & 0.0065 & 0.54 \\
\hline Aut. & - & $65.8^{\mathrm{aB}}$ & $64.5^{\mathrm{abBC}}$ & $62.6^{\mathrm{bA}}$ & & - & - & _ \\
\hline Spr. & $73.5^{\mathrm{B}}$ & $63.6^{\mathrm{B}}$ & $62.2^{\mathrm{C}}$ & $56.3^{\mathrm{B}}$ & & $\hat{\mathrm{Y}}=73.69-0.0379 \mathrm{X}$ & $<0.0001$ & 0.97 \\
\hline Sum. 2 & $76.5^{\mathrm{A}}$ & $72.9^{\mathrm{A}}$ & $69.6^{\mathrm{A}}$ & $57.2^{\mathrm{B}}$ & & $\hat{Y}=78.00-0.0527 X$ & $<0.0001$ & 0.92 \\
\hline \multicolumn{9}{|c|}{ LIG (g kg-1 DM) } \\
\hline Sum. 1 & $5.1^{B}$ & $4.9^{\mathrm{AB}}$ & $4.8^{\mathrm{AB}}$ & $4.5^{\mathrm{AB}}$ & \multirow{4}{*}{0.3} & $\hat{\mathrm{Y}}=4.8$ & ${ }^{\mathrm{T}} \mathrm{NS}$ & NS \\
\hline Aut. & - & $4.7^{\mathrm{aB}}$ & $5.2^{\mathrm{aA}}$ & $5.0^{\mathrm{aA}}$ & & 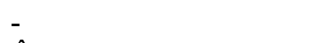 & - & - \\
\hline Spr. & $6.0^{\mathrm{A}}$ & $5.2^{\mathrm{AB}}$ & $4.5^{\mathrm{AB}}$ & $3.5^{\mathrm{C}}$ & & $\hat{Y}=6.08-0.007 X$ & $<0.0001$ & 0.76 \\
\hline Sum. 2 & $6.5^{\mathrm{A}}$ & $5.2^{\mathrm{A}}$ & $4.5^{\mathrm{B}}$ & $3.7^{\mathrm{BC}}$ & & $\hat{\mathrm{Y}}=5.99-0.0063 \mathrm{X}$ & $<0.0001$ & 0.85 \\
\hline \multicolumn{9}{|c|}{ NDIP (g kg-1 DM) } \\
\hline Sum. 1 & $0.75^{\mathrm{B}}$ & $1.22^{\mathrm{A}}$ & $1.25^{\mathrm{A}}$ & $1.42^{\mathrm{A}}$ & 0.05 & $\hat{\mathrm{Y}}=0.85+0.0017 \mathrm{X}$ & $<0.0001$ & 0.70 \\
\hline Aut. & - & $1.05^{\mathrm{aAB}}$ & $1.36^{\mathrm{aAB}}$ & $1.50^{\mathrm{aA}}$ & 0.20 & - & - & - \\
\hline Spr. & $1.05^{\mathrm{A}}$ & $0.96^{\mathrm{B}}$ & $1.08^{\mathrm{B}}$ & $1.46^{\mathrm{A}}$ & 0.06 & $\hat{\mathrm{Y}}=0.93+0.0011 \mathrm{X}$ & 0.0061 & 0.65 \\
\hline Sum. 2 & $1.23^{\mathrm{A}}$ & $1.20^{\mathrm{A}}$ & $1.21^{\mathrm{AB}}$ & $1.29^{\mathrm{A}}$ & 0.07 & $\hat{\mathrm{Y}}=1.23$ & NS & NS \\
\hline \multicolumn{9}{|c|}{ ADIP (g kg-1 DM) } \\
\hline Sum. 1 & $0.37^{\mathrm{B}}$ & $0.36^{\mathrm{A}}$ & $0.35^{\mathrm{A}}$ & $0.26^{\mathrm{A}}$ & 0.02 & $\hat{\mathrm{Y}}=0.38-0.0003 \mathrm{X}$ & 0.0277 & 0.24 \\
\hline Aut. & - & $0.22^{\mathrm{aB}}$ & $0.21^{\mathrm{aB}}$ & $0.21^{\mathrm{aAB}}$ & 0.03 & - & - & - \\
\hline Spr. & $0.46^{\mathrm{A}}$ & $0.35^{\mathrm{A}}$ & $0.29^{\mathrm{A}}$ & $0.25^{\mathrm{A}}$ & 0.02 & $\hat{Y}=0.44-0.0006 \mathrm{X}$ & $<0.0001$ & 0.69 \\
\hline Sum. 2 & $0.48^{\mathrm{A}}$ & $0.37^{\mathrm{A}}$ & $0.29^{\mathrm{A}}$ & $0.18^{\mathrm{B}}$ & 0.01 & $\hat{\mathrm{Y}}=0.48-0.0008 \mathrm{X}$ & $<0.0001$ & 0.96 \\
\hline
\end{tabular}

Means followed by different lowercase and uppercase letters in the same row and column, respectively, are significantly different $(\mathrm{P}<0.05)$ according to Student's t-test $(\mathrm{PDIFF})$. SEM=standard error of the mean. P: equation regression significant. $\mathrm{R}^{2}$ : determination coefficient.

The neutral detergent fibre contents fit a positive quadratic regression model, and an estimated maximum value of $67 \mathrm{~g} \mathrm{~kg}^{-1} \mathrm{DM}$ was recorded, which corresponded to a fertilisation rate of $190 \mathrm{~kg} \mathrm{ha}{ }^{-1} \mathrm{~N}$ and $\mathrm{K}_{2} \mathrm{O}$ in the summer of 2010/2011. This performance most likely resulted from the marked water deficit in the summer (Table 1). However, a significant negative linear response was observed with increased fertilisation in the spring and summer of 2011/2012, possibly due the effect of greater $\mathrm{N}$ availability, which increased the use of available carbohydrates in the production of cytoplasmic components rather than thickening the cell walls by the accumulation of polymeric substances (FAGERIA; CARVALHO, 2014). A reduction in the neutral detergent fibre values is important because these are the most limiting factors for forage intake according to Van Soest (1994), and values of cell wall components higher than 55-60 g $\mathrm{kg}^{-1} \mathrm{DM}$ are negatively correlated with forage intake. The results found in the present study are similar to the findings of Vitor et al. (2009), who studied elephant grass under four $\mathrm{N}$ levels $(100,300,500$ and $700 \mathrm{~kg} \mathrm{ha}^{-1}$ ), and Johnson et al. (2001), who studied star grass to determine the effect of five $\mathrm{N}$ levels $\left(0,39,78,118\right.$ and $\left.157 \mathrm{~kg} \mathrm{ha}^{-1}\right)$ on the neutral detergent fibre contents and noted a decrease in the values from 76.9 to $72.0 \mathrm{~g} \mathrm{~kg}^{-1} \mathrm{DM}$ from the lowest to the highest levels applied.

Lignin decreased linearly in the spring and summer of 2011/2012 (Table 6) but did not fit a specific regression model in the summer of
2010/2011, and a mean value of $4.8 \mathrm{~g} \mathrm{~kg}^{-1} \mathrm{DM}$ was recorded. As for the FDN, the linear reduction of lignin in the spring and in Sum. 2 is beneficial for animal nutrition (VAN SOEST, 1994) in these stations. The protein associated with the cell wall (neutral detergent insoluble protein and acid detergent insoluble protein) varied between treatments within seasons, and a defined pattern was not observed (Table 6). The neutral detergent insoluble protein increased linearly with the levels of fertiliser in the summer and spring of 2010/2011, although the data did not fit a specific regression model in the summer of 2011/2012, and a mean value of $1.2 \mathrm{~g} \mathrm{~kg}^{-1} \mathrm{DM}$ was recorded. This increase resulted from plant growth that was promoted by fertilisation, which likely led to a higher ratio of components responsible for plant support. The acid detergent insoluble protein content, which corresponds to unavailable protein, showed no variation with treatments in autumn, and a mean value of $0.21 \mathrm{~g} \mathrm{~kg}^{-1} \mathrm{DM}$ was recorded. During the summer of 2010/2011 and the spring and summer of $2011 / 2012$, a linear negative regression model was fit for this variable, and this result is associated with decreased acid detergent fibre because the acid detergent insoluble protein fraction is also a component of this. Lower acid detergent insoluble protein values are desirable because this component is associated with lignin and Maillard reaction products and forms complexes with tannins, which are resistant to microbial and enzymatic degradation (BALSALOBRE et al., 2003). 


\section{CONCLUSIONS}

$\mathrm{N}$ and $\mathrm{K}$ fertilisation and the climate changes jointly affect the forage mass, morphological components, accumulation and nutritive value of Urochloa ruziziensis.

$\mathrm{N}$ and $\mathrm{K}$ fertilisation up to $360 \mathrm{~kg} \mathrm{ha}^{-1}$ year $^{-1}$ improves the forage accumulation and nutritive value of $U$. ruziziensis because it increases the crude protein and in vitro dry matter digestibility and reduces the neutral detergent fibre and lignin contents of forage.

\section{REFERENCES}

ALVES, L. W. R. Produção e dinâmica de degradação da fitomassa de planta para cobertura do solo no sistema plantio direto em Paragominas, PA. 1. ed. Macapá: Embrapa, 2015. 20 p. (Boletim de pesquisa e desenvolvimento n. 90).

BALSAlOBRE, M. A. A. et al. Composição química e fracionamento do nitrogênio e dos carboidratos do capim-Tanzânia irrigado sob três Níveis de Resíduo Pós-pastejo. Revista Brasileira de Zootecnia, Viçosa, v. 32, n. 3, p. 519-528, 2003.

CARNEVALLI, R. A. et al. Desempenho de ovinos e respostas de pastagens de Tifton 85 (Cynodon spp.) sob lotação contínua. Scienthia Agricola, Piracicaba, v. 58, n. 1, p. 7-15, 2001

CARNEVALLI, R. A. et al. Herbage production and grazing losses in Panicum maximum cv. Mombaça under four grazing managements. Tropical Grasslands, Colombia, v. 40, n. 2, p. 165-176, 2006.

CORRÊA, L. A. et al. Efeito de fontes e doses de nitrogênio na produção e qualidade da forragem de capim-coastcross. Revista Brasileira de Zootecnia, Viçosa, v. 36, n. 4, p. 763-772, 2007.

COSTA, K. A. P.; OLIVEIRA, I. P.; FAQUIN, V. Adubação nitrogenada para pastagens do gênero Urochloa em solos do Cerrado. 1. ed. Santo Antônio de Goiás: Embrapa, 2006. 60 p. (Documento 192).

Da SILVA, S. C. Conceitos básicos sobre sistemas de produção animal em pastos. In: ANAIS DO SIMPÓSIO SOBRE MANEJO DA PASTAGEM. 2009, Piracicaba. Anais... Piracicaba: FEALQ, 2009. p. 07-35.

FAGERIA, N. K.; CARVALHO, M. C. S. Comparison of conventional and polymer coated urea as nitrogen sources for lowland rice production. Journal of Plant Nutrition, Temuco, v. 37, n. 37, p.
1358-1371, 2014.

FAGUNDES, J. L. et al. Acúmulo de forragem em pastos de Urochloa decumbens adubados com nitrogênio. Pesquisa Agropecuária Brasileira, Brasília, v. 40, n. 40, p. 397-403, 2005.

FAGUNDES, J. L. et al. Avaliação das características estruturais do capim-braquiária em pastagens adubadas com nitrogênio nas quatro estações do ano. Revista Brasileira de Zootecnia, Viçosa, v. 35, n. 35, p. 30-37, 2006.

FONSECA, D. M.; MARTUSCELLO, J. A. Plantas Forrageiras. 1. ed. Viçosa, MG: UFV, 2010. 460 p.

GOMES, M. B. et al. Morfogênese na germinação e na fase de estabelecimento da Brachiaria ruziziensis submetida à adubação nitrogenada e potássica. Ciência Rural, Santa Maria, v. 42, n. 12, p. 2235 2241, 2012.

FREIRE, L. R. et al. Manual de calagem e adubação do Estado do Rio de Janeiro. 1. ed. Seropedica, RJ: UFRRJ, 2013. 430 p.

JOHNSON, C. R. et al. Effects of nitrogen fertilization and harvest date on yield, digestibility, fiber, and protein fractions of tropical grasses. Journal of Animal Science, Champaign, v. 79, n. 9 , p. 2439-2448, 2001.

KOTTEK, M. et al. World Map of the KöppenGeiger climate classification updated. Meteorologische Zeitschrift, Berlim, v. 15, n. 3, p. 259-263, 2006.

LIMA, J. E. S. et al. Urochloa ruziziensis responses to sources and doses of urea. Revista Brasileira de Engenharia Agrícola e Ambiental, Campina Grande, v. 20, n. 5, p. 401-407, 2016.

MAGALHÃES, A. F. et al. Influência do nitrogênio e do fósforo na produção do capim-braquiária. Revista Brasileira de Zootecnia, Viçosa, v. 36, n. 36, p. 1240-1246, 2007.

MALAFAIA, P. A. M., VIEIRA, R. A. M. Técnicas de determinação e avaliação dos compostos nitrogenados em alimentos para ruminantes In: SIMPÓSIO INTERNACIONAL DE DIGESTIBILIDADE EM RUMINANTES, Lavras, 1997. Anais... Lavras: FAEPE, 1997. p. 29-54.

MARANHÃO, C. M. A. Características produtivas, morfogênicas e estruturais do capim-braquiária submetido a intervalos de cortes e adubação nitrogenada. 2008. $61 \mathrm{f}$. Dissertação (Mestrado em Zootecnia: Área de Concentração em Produção de Ruminantes) - 
Universidade Estadual do Sudoeste da Bahia, Itapetinga, 2011.

MOORE, J. E.; MOTT, G. O. Recovery of residual organic matter from in vitro digestion of forages. Journal of Dairy Science, Champaign, v. 57, n. 10, p. 1258-1259, 1974.

MOREIRA, L. M. et al. Perfilhamento, acúmulo de forragem e composição bromatológica do capim-braquiária adubado com nitrogênio. Revista Brasileira de Zootecnia, Viçosa, v. 38, n. 9, p. 6751684, 2009.

SILVA, D. J.; QUEIROZ, A. C. Análise de alimentos: métodos químicos e biológicos. 2. ed. Viçosa, MG: UFV, 2002. 235 p.

SOUSA, R. S. et al. Composição química de capim-tanzânia adubado com nitrogênio e fósforo. Revista Brasileira de Zootecnia, Viçosa, v. 39, n. 6, p. 1200-1205, 2010.

THORNTHWAITE, C.W.; MATHER, J.R. The water balance. 1 ed. New Jersey: Laboratory of Climatology, 1955. 104 p.

TILlEY, J. M. A.; TERRY, R. A. A two-stage technique for the in vitro digestion of forage crop. Journal of Bristish Grassland Society, Dumfries, v. 18, n. 2, p. 104-111, 1963.

TOWNSEND, C. R. et al. Características morfogênicas e estruturais de Brachiaria ruziziensis submetida ao sombreamento. 1. ed. Porto Velho: Embrapa, 2013. 5 p. (Circular técnica n. 135).

VAN SOEST, P. J. Plant, animal and environment. In: VAN SOEST, P. J. (Ed.). Nutritional ecology of the ruminant. 2 ed. New York: Cornell University Press, 1994. v. 1, cap. 6, p. 77-92.

VAN SOEST, P. J.; ROBERTSON, J. B.; LEWIS, B. A Methods for dietary fiber, neutral detergent fiber, and non-starch polysaccharides in relation to animal nutrition. Journal of Dairy Science, Champaign, v. 74, n. 10, p. 3583-97, 1991.

VITOR, C. M. T. et al. Produção de matéria seca e valor nutritivo de pastagem de capim-elefante sob irrigação e adubação nitrogenada. Revista Brasileira de Zootecnia, Viçosa, v. 38, n. 3, p. 435-442, 2009.

WOLFINGER, R. D. Covariance structure selection in general mixed models. Communications in Statistics Simulation and Computation, Philadelphia, v. 22, n. 4, p. 1079-1106, 1993. 